\title{
Psalm 56 Read within its Literary Context in the Psalter and its Connections with King David
}

\author{
J. H. (Henk) Potgieter (University Of Pretoria)
}

\begin{abstract}
The heading of Ps 56 connects the psalm with "David," and specifically with the time when he was "seized" by the Philistines in Gath. The psalm can be described as a lament with a strong emphasis on trust in God and praise for his word. This article investigates the reasons why the editors made this connection with the experience of David and how the intertextual connections this heading creates modifies the hermeneutical horizon of the psalm. It is suggested that the psalm, in view of its heading, serves to exonerate David from the fear that he experienced according to 1 Sam 21:13. It also focuses the attention of its readers on the way in which David triumphed in a situation of unjust persecution through his trust in Yahweh in order to walk freely in praise of God.
\end{abstract}

\section{A INTRODUCTION}

Psalm 56 is rather unique within the book of Psalms. It can be described as a lament or a supplication with a strongly emphasised confession of trust. ${ }^{1}$ It is as though the psalmist encourages himself amidst a situation of serious oppression and attack so energetically that a complete contrast is created between the beginning and end of the psalm. In the beginning there is talk of enemies pursuing the suppliant "all day long" (56:2-3); in the end the danger seems to have been resolved because God has "delivered" his "soul" from death, his feet from falling, and has opened the possibility for him to "walk before God in the light of life" (56:13).

The peculiar structure of the psalm as a lament and the development of its contents from a plea for grace to a promise of praise already provide ample

* Article submitted: 28 September 2015; accepted 20 October 2015. To cite: J. H. (Henk) Potgieter, "Psalm 56 Read within its Literary Context in the Psalter and its Connections with King David," Old Testament Essays (New Series) 28 no. 3 (2015): 760-776. DOI: http://dx.doi.org/10.17159/2312-3621/2015/v28n3a12

1 According to Frank-Lothar Hossfeld and Erich Zenger, Psalm 51-100 (vol. 2 of Die Psalmen; KAT; Würzburg: Echter, 2002), 351, the elements of lament, supplication, and promise of praise are easily recognised, but instead of God being accused of the affliction, a confession of trust dominates the composition. Klaus Seybold, Die Psalmen (HAT I/15; Tübingen: J. C. B. Mohr [Paul Siebeck], 1996), 225 describes the psalm as a prayer which was only recorded after the rescue of the suppliant with a view to thanksgiving ("Dankfeier"). 
reason for investigating it more closely. The research question which drives this particular investigation, however, is particularly interested in the connections between the superscript of the psalm and its contents. Psalm 56 is one of 13 psalms, many of which are located in the vicinity of this one, ${ }^{2}$ which were supplied by a superscript connecting the psalm to the life of David. Why was this particular context from 1 Samuel chosen to establish a historical context for its interpretation? What were the concerns of the editors who wanted to portray "David" as the suppliant? It seems that the one incident in the life of David where he "was very afraid" (1 Sam 21:13, וירא מאד) served as a cue for the editors to establish a connection, since Ps 56:4 says, "On (the) day when I am afraid (יום אירא), I will put my trust in you." After this verse, the suppliant twice more states that he trusts in God and "shall not be afraid" ( 56:5 and 12) because his enemies are only human. Perhaps the editors wanted to use the example of the literary figure of David to provide encouragement to their fellow believers. If it happens that you are attacked by proud opponents who oppress you continually and you become very afraid, put your trust in God, remember that your enemies are mere humans and that God had once saved "David" from a similar threat in a miraculous way.

Beat Weber has argued that such biographical headings in particular can be described as "metatexts," texts in their own right which establish connections between the text of the psalm itself, the body of authoritative literature (intertextual connections with especially the books of Samuel), institutions (in those instances where indications are provided for the performance of a psalm), and the immediate context of the particular psalm in the book of Psalms (the preceding and succeeding psalms which he describes as "paratexts"). ${ }^{3}$ Such a heading therefore serves to contextualise the psalm in many different ways which all serve to aid with its understanding. These contexts will be consulted in an attempt to determine what Ps 56 meant to the editors who arranged the sequence of psalms and who composed the particular heading for use with Ps 56.

2 The eight occurrences within the second collection of Davidic psalms (Pss 51-72) changes this rather small collection into one that has the most conspicuous ties with David. Weber similarly describes Pss 51, 52, 54, 56, 57, 59, 60 and 63 as the "Schwerpunkt" of the second Davidic collection. Cf. Beat Weber, "An dem Tag, als JHWH ihn rettete aus der Hand aller seiener Feinde und aus der Hand Sauls' (Ps 18:1): Erwägungen zur Anordnung der biographischen Angaben zu David im Psalter," $V T$ 64 (2014): 284-304, 288.

3 Beat Weber, “An dem Tag," 285. Weber's argument is that Ps 18, where the heading refers to David's victory over all his enemies and Saul, is a key text which helps the reader to understand that the distress was stopped decisively and that the psalms should be read from the perspective of praise given to Yahweh for his salvation. Cf. Weber, “An dem Tag,” 293. 


\section{B THE TEXT AND STRUCTURE OF PSALM 56}

The text of Ps 56 consists of various parts, namely a heading in v. 1 and the body of the psalm from v. 2 to v. 14, which also includes two "confessions." To understand the possible connections which the editors saw between the heading and the body of the psalm, it is necessary to start the investigation with the body of the psalm. After the discussion of the stichometric analysis of vv. 2-14 and its constituent parts, the heading will also be scrutinised to determine what the nature of its components is. In the third and last instance the possible reasons for the connection made by the editors will be discussed.

Regarding the various problems and questions with which the psalm presents us, the following remark of Fokkelman is applicable: "This song is an interesting test case, in view of colometry as well as the determination of the correct [sic] structure." ${ }^{4}$ Apart from some minor differences there seems to be a consensus among modern researchers regarding the main divisions in the poem. ${ }^{5}$ Although Fokkelman and Van der Lugt disagree regarding the precise demarcation of the strophes, both affirm the existence of six strophes. I agree partially with the analysis of Weber and Raabe ${ }^{6}$ in the sense that I also consider the body of the poem to have four strophes and two separate confessions. Therefore I use the symbols $\mathrm{X}^{1}$ and $\mathrm{X}^{2}$ in the stichometric analysis to indicate that the confessions are not part of the main body of the poem.

\section{Table 1: A Rendering of the Structure of Psalm 56}

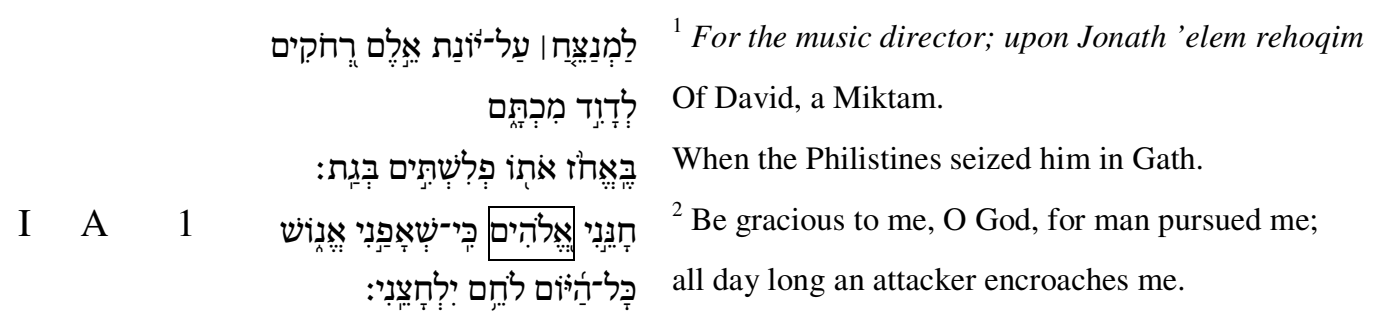

4 Johannes P. Fokkelman, 85 Psalms and Job 4-14 (vol. 2 of Major Poems of the Hebrew Bible; Assen: Van Gorcum, 2000), 174-177.

5 Hossfeld and Zenger, Die Psalmen 50-100, 351, make use of form critical categories like "Notschilderung," "Vertrauensbekenntnis" and "Lobgelübde" in their discussion to distinguish between five different sections in the poem.

6 Beat Weber, Die Psalmen 1 bis 72 (vol. 1 of Werkbuch Psalmen; Stuttgart: Kohlhammer, 2001), 250-251 follows Paul R. Raabe, Psalm Structures: A Study of Psalms with Refrains (Sheffield: JSOT Press, 1990), 104 in a rather interesting division, where they both acknowledge the existence of four strophes and two refrains but the refrains do not form part of their strophe count and are counted as separate entities. Hans-Joachim Kraus, Psalmen 1-63 (vol. 1 of Psalmen; BKAT 15/1; Neukirchen-Vluyn: Neukirchner Verlag, 1960), 408 has a more extreme opinion about the two refrains. He thinks that, apart from the fact that it disturbs the flow of thoughts and that they are not really refrains, "Von einem Kehrreim in 5a und 11 kann keine Rede sein.” 


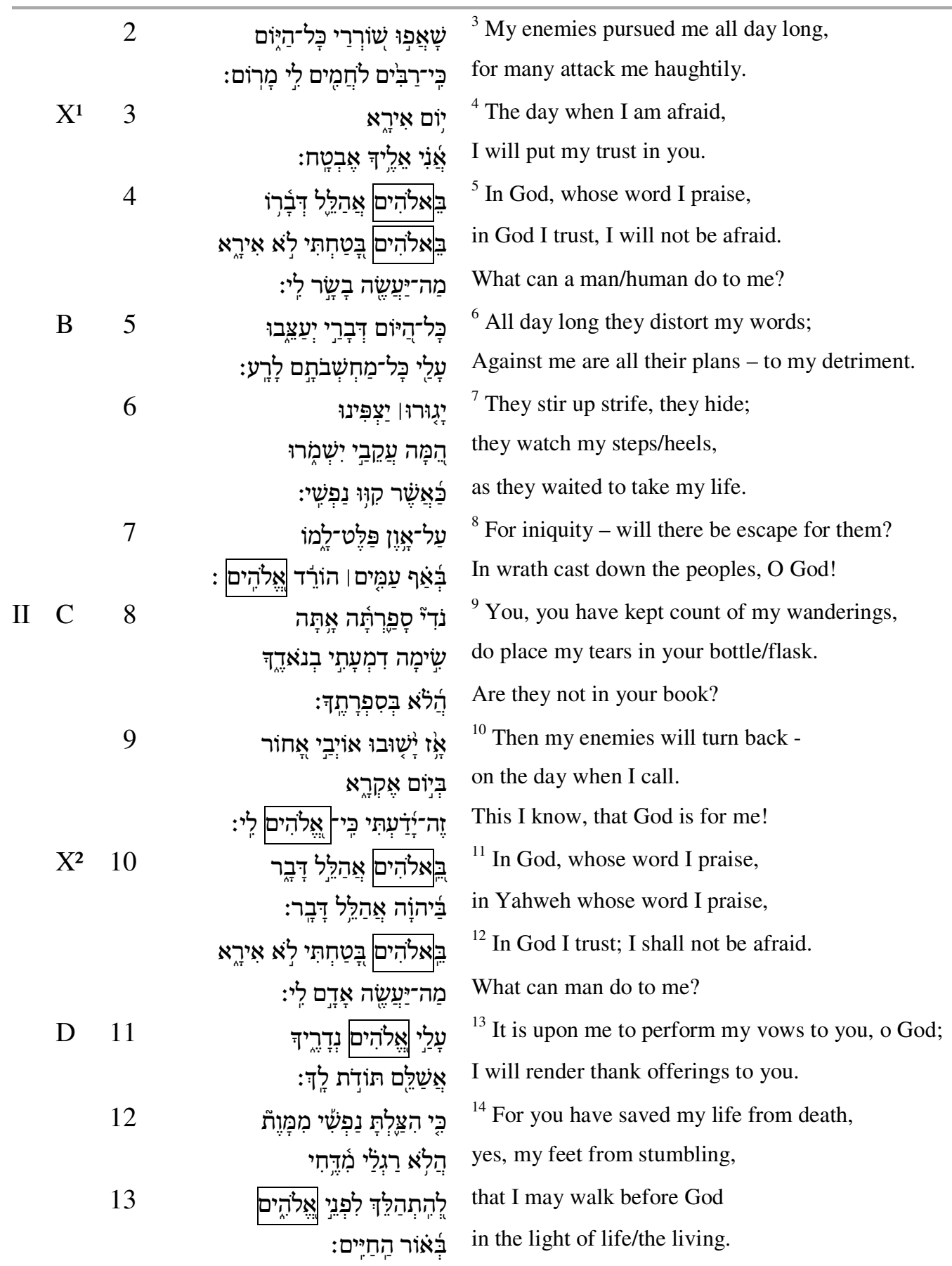

The arrangement of the four strophes and the two "confessions" is done in the following way: Strophe A consists of vv. 2-3, Strophe $X^{1}$ of vv. 4-5, Strophe B of vv. 6-8, Strophe C of vv. 9-10, Strophe $\mathrm{X}^{2}$ of vv. 11-12 and Strophe D of vv. 13-14.

As is evident from the presentation of the structure above, the psalm consists of two stanzas (I and II) which each have two strophes (A and B and C 
and D). The first stanza constitutes a prayer for mercy and describes the persecution the suppliant suffered. In the second stanza, there is a complete change in the mood of the suppliant. The psalmist is aware of the fact that God has taken note of all his suffering and is confident that God is on his side. Therefore he promises to keep his vows of thanksgiving.

Apart from the logical flow of thoughts and motifs within the stanzas there also seems to be, when the two stanzas are placed next to one another, an intricate play of words, themes and motifs between the respective strophes.

Table 2: Comparison between the Two Stanzas of Psalm 56

A1

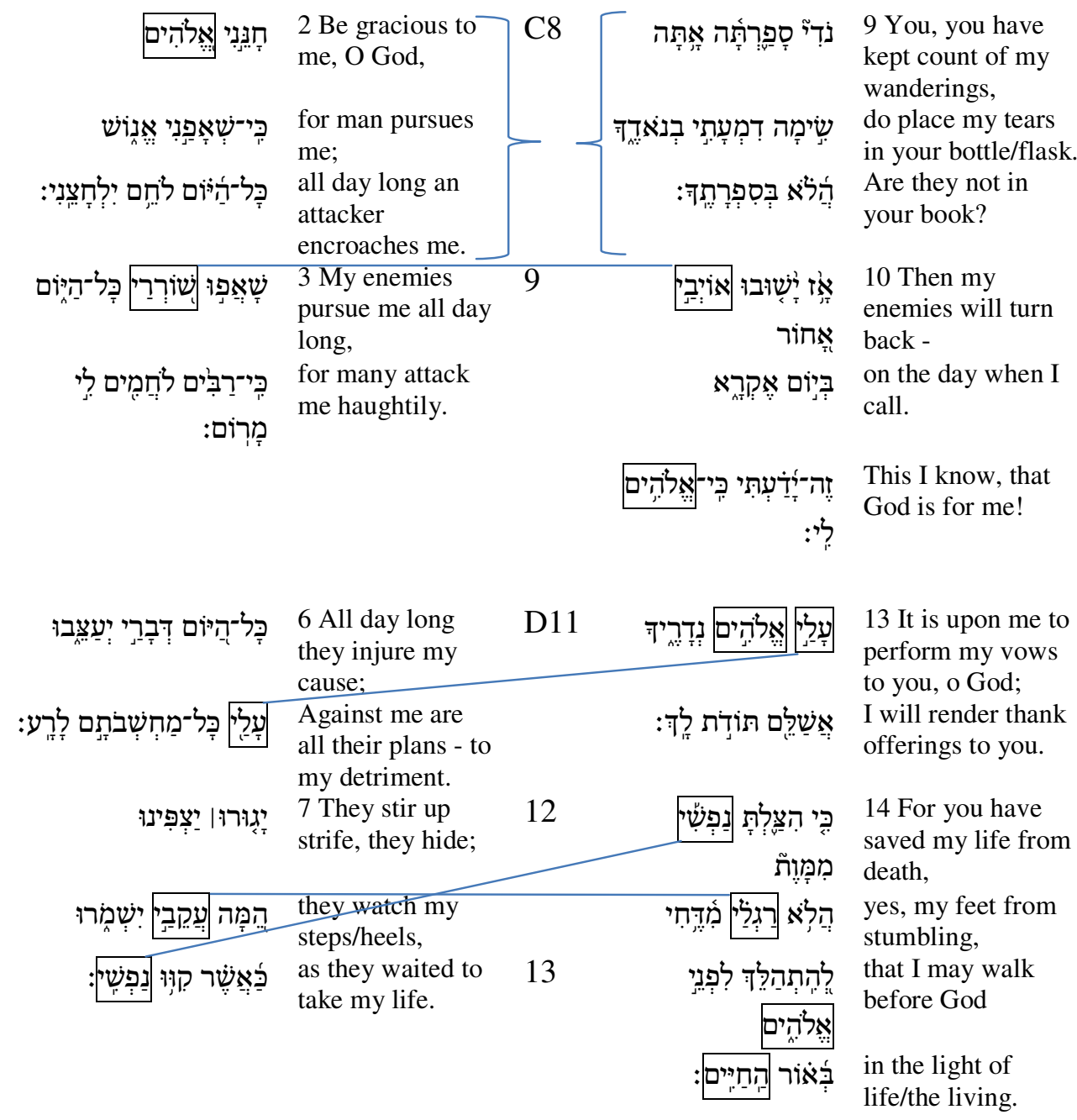




\section{The Two Confessions $X^{1}$ and $X^{2}$ in Psalm 56}

Regarding the boundaries of strophe $\mathrm{X}^{1}$, there is a difference of opinion. The colometry of v. 4 and the extent of the confession are contested. ${ }^{7}$ There are two reasons why I agree with Fokkelman about the inclusion of v. 4 in the confession. First and foremost, as was reasoned above, vv. 2 and 3, which constitute strophe A, form such a tight-knit unit that v. 4, when added to them, seems superfluous. The second reason stems from the comparison between the two confessions. Without v. $4, \mathrm{X}^{1}$ is out of balance with $\mathrm{X}^{2}$.

Table 3: The Two Confessions in Psalm 56

\begin{tabular}{|c|c|c|}
\hline \multirow[t]{4}{*}{$X^{1}$} & 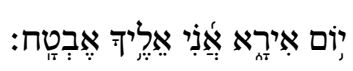 & 4 The day when I am afraid, I will put my trust in you. \\
\hline & 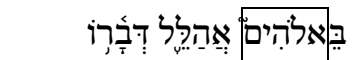 & 5 In God, whose word I praise, \\
\hline & 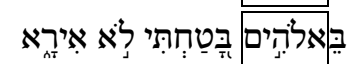 & in God I trust, I will not be afraid. \\
\hline & 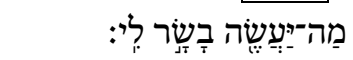 & What can a man/human do to me? \\
\hline \multirow[t]{4}{*}{$\mathrm{X}^{2}$} & 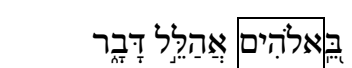 & 11 In God, whose word I praise, \\
\hline & 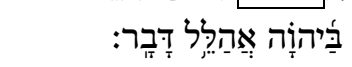 & in Yahweh whose word I praise, \\
\hline & 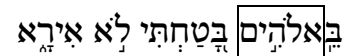 & 12 In God I trust; I shall not be afraid. \\
\hline & מַה־־יְעַשֶׁה אָדָּם לְי: & What can man do to me? \\
\hline
\end{tabular}

These two confessions of the suppliant seem to have been added by an editor to a pre-existing psalm. The reasons for this notion are, first, there are close connections between these two similar sections and the book of Jeremiah, specifically Jer 9:22-23 and Jer 17:5. In the second place, different from what one would expect in the case of a refrain, they contain motifs not found in the rest of the psalm. They present novel ideas in the form of an expression of trust in God; a confession of not being afraid, and a rhetorical question which is meant to emphasise the inability of human enemies to harm the believer when God is on his side. A third reason is that a refrain is always used to open or to conclude a strophe or stanza, while with these two sections of text, they seem to have been inserted between two existing stanzas so that the logical flow of the poem is interrupted. The contents of the two sections also link up so well with the setting suggested in the heading, namely David's distress among the Philistines, that it can be surmised that they were inserted by the same hand that inserted the historical connection to "David."

7 Both Fokkelman, Major Poems 2, 175 and Pieter van der Lugt, Psalms 42-89 (vol. 2 of Cantos and Strophes in Biblical Hebrew Poetry; Leiden: Brill, 2010), 134 take v. 4 as a monocolon, while Raabe, Psalm Structures, 90-91, Hossfeld and Zenger, Die Psalmen 51-100, 352 and Weber, Werkbuch 1, 250 consider it to be a bicolon. Fokkelman, Major Poems 2, 175 makes a strong case for v. 4 to be part of the refrain while Raabe and Weber see it as part of the first strophe. 
There is development between the two "confessions": The first one begins with a reference to an instance of fear, but this is excluded in the second "confession." In its place, and so as to balance for its absence, an additional expression of trust is inserted in the second "confession," so that this aspect is emphasised over against the fear which dominates in the first "confession." In this way, there is a movement from the possibility of fear to an overwhelming expression of trust between the two sections. In the case of the second "confession," the reference to "God" is supplemented by a reference to "Yahweh," a fact which perhaps also serves as a pointer to its having been added later. ${ }^{8}$

It is interesting that human opponents are described in the first "confession" as "flesh," and in the second "confession" as "a human." The only intertextual context that throws light on this development is Jer 17:5 where a curse is pronounced on any person who puts his trust in humans instead of in Yahweh. The word-pair "man" (אדם) and "flesh" (בשר) is used to describe this wrong kind of trust. Used in a confession of trust in Yahweh, and expressing disregard for human power, the two words are used in reversed order in Ps 56 with a contrasting exclamation of positive trust in God.

The function of the two "confessions" in Ps 56 can therefore be described as a strategy for turning an original lament or supplication for help into a confession of trust and a promise of praise. By alluding to Jer 17:5 and Jer 9:23, the editor succeeded in providing "David" with a profile resembling that of "Jeremiah." In this way "Scripture" (the "word" of God) is involved in providing support to the in-group of the editors in the post-exilic period. If the group of psalms from Ps 52 is used to identify the editors who grouped them together, it would seem that they were wisdom-inspired believers who worked

8 Cf. the remark by Samuel Terrien, The Psalms: Strophic Structure and Theological Commentary (ECC; Grand Rapids, Mich.: Eerdmans, 2003), 432, in this regard.

9 Seybold, Psalmen, 226 explains the "word" of God here as the "Urteilsspruch Gottes" in a situation of someone who has been accused wrongfully. He says it displays the attitude of trust of someone who lets everything depend on the decision of God, therefore the use of the preposition בטח ב or. There is no suggestion of somebody being accused wrongfully in the present form of Ps 56, however. According to Hossfeld and Zenger, Die Psalmen 51-100, 351, the psalm does not fit the institutional requirements to be a prayer for an accused, but is much easier visualised in the context of private piety. Hossfeld and Zenger, Die Psalmen 51-100, 354 , consequently rather think of the broad stream of protective and rescuing "Gottesworte," especially in the prophetic books. 
between the middle of the fifth century and the second half of the fourth century B.C.E. ${ }^{10}$

\section{THE HEADING OF PSALM 56}

The superscript of Ps 56 consists of the following elements: (1) A liturgical note, "For the musical director." (2) The title or possibly the melody which should be used to perform the song, "According to the dove on distant terebinths."11 (3) The author or composer: "Of David." (4) The Gattung: "A Miktam," which could possibly be translated as "An Inscription." There are only six psalms described as "Miktam" in the Psalter - the five in the cluster 56-60, as well as Ps 16 in Book 1. Although, according to Zenger, the term Cluster12 is used for a group of psalms with the same Gattung, he himself uses the term to indicate the broader collection of psalms, namely Pss 51-64. This group, however, includes psalms with different Gattung descriptions, for

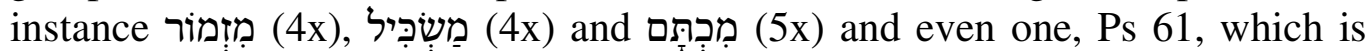
without any Gattung designation. For the subdivision of this cluster into subgroups with similar themes, Zenger uses the term "Untergruppe." The five psalms, 56-60, with the designation form such a subgroup ("Untergruppe") within the cluster 51-64. (5) The temporal phrase "When the Philistines seized him in Gath." This is a historical reference to the episode in 1 Sam 21:11 when David arrived among the Philistines after his initial flight from Saul.13

10 Walter Beyerlin, Der 52. Psalm, Studien zu seiner Einordnung (Stuttgart: W. Kohlhammer, 1980), 95.

11 Seybold, Psalmen, 225 translates "Taube der fernen Götter." The cue for "gods" he finds in Pss 29:1; 58:2 and 82:1, while he considers a "dove" to be a symbol of the messengers of the gods (he refers to Gen 8:8-12). This interpretation is also found in Christopher T. Begg, “'Dove' and 'God(s)' in Ps 56:1," ETL 64 (1988): 393-396. It causes more problems than it solves, however. The "dove" in the title more probably merely establishes a connection with the body of Ps 55, namely Ps 55:7. Hossfeld and Zenger, Die Psalmen 51-100, 354 also refer to the tradition about a dove as the messenger of the gods, but think that it symbolises the message of the suppliant to the far-off God Yahweh, and that the Gattung "Miktam" supports this if it is translated as "Inschrift/Brief" (inscription/letter). Marvin E. Tate remarks that the use of "letter prayers" was fairly common in the ANE. Cf. Marvin E. Tate, Psalms 51-100 (WBC 20; Dallas: Word Books, 1990), 66.

12 Erich Zenger, "Psalmenexegese und Psalterexegese: Eine Forschungsskizze," in The Composition of the Book of Psalms (ed. Erich Zenger; BETL 238; Leuven: Peeters, 2010), 41-42.

13 Martin Kleer, "Der liebliche Sänger der Psalmen Israels": Untersuchungen zu David als Dichter und Beter der Psalmen (BBB, 108; Bodenheim: Philo, 1996), 99 points out that Ps 56 is connected to 1 Sam 21:11-16 through the play on the stem הלל , the fear David experienced, and his flight (through use of the stem 


\section{THE CONNECTIONS OF PSALM 56 WITH THE CLUSTER PSALMS 52-64}

Zenger states that Ps 56 is undeniably part of the composition of laments and supplicatory prayers formed by 52-64 which begins with a subgroup of psalms in which laments dominate, namely $52-55$, and that this is then followed by the subgroup consisting of Pss 56-59 + 60 in which there is a stronger focus on supplication and trust. ${ }^{14}$ Certainty that Ps 56 was meant to continue the subgroup of 52-55 is provided, according to Zenger, by the concluding sentence of Ps 55:24c which was inserted by the editors. ${ }^{15}$ However, the wrong and the correct type of trust already plays an important role in Ps 52, namely trust in one's riches or trust in the steadfast love of God (cf. Ps 52:9 and 10). The confession of trust in Ps 55:24 links up with the similar confession in Ps 52:10, and both psalms clearly demonstrate influence from Ps 49:7 and Jer 9:23. ${ }^{16}$ It was argued above that Jer 9:23 must have played a role in the editing of Ps 56 as well, while Jer 17 also seems to have played a role in the composition of Ps 52 and in the editing of Ps 56. Jeremiah 17:5 pronounces a curse on the "man" (ביבֶר) who trusts (בטח) in "man" (בשדם), who makes "flesh" (בשר) his strength, and whose heart thus turns away from Yahweh. Jeremiah 17:7 praises in turn the "man" (בֶֶֶ) who "trusts" (בטחר) in Yahweh and whose "trust" (מבטח) is Yahweh. It is as though the editors of Ps 56 wanted to draw attention to the lexical connection they created with Jer 17:5 by having the suppliant declare that he "trusts" (בטח) in God, for what can "flesh" (בשר) do to him (Ps 56:5) and later on again, that he trusts in God, for what can "man" (אדם) do to him (Ps 56:12). ${ }^{17}$ It would seem, therefore, that the same editorial hand which composed Ps 52 was at work in the adaptation of Pss 55 and 56 for inclusion in this cluster. ${ }^{18}$

Psalm 56 also has close ties with Ps 57, to such an extent that Rudolf Kittel remarks that they are so similar, that they must have been composed by the same person. ${ }^{19}$ Psalm 57 also has a kind of refrain in vv. 6 and 12 and uses

14 Hossfeld and Zenger, Die Psalmen 51-100, 352.

15 Hossfeld and Zenger, Die Psalmen 51-100, 352.

16 The influence of Jer 9 on the composition of Ps 52 and the editorial reworking of Ps 55 is a topic which has been researched by my colleague, Phil Botha.

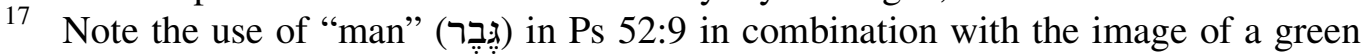
tree (52:10), reminiscent of the image of a tree planted by water in Jer 17:8.

18 The root of the word in Ps 56:9, "wanderings," is נד and this establishes a wordplay connection with the suppliant's wish to "flee" in Ps 55:8. Cf. HALOT: s.v. T', entry 5981. Hossfeld and Zenger, Die Psalmen 51-100, 354 find a connection between the flight or the wandering of the suppliant in Ps 56:9 and the note about David's "flight" from Saul in 1 Sam 21:11.

19 Rudolf Kittel, Die Psalmen (KAT 13; Leipzig: A. Deichertsche Verlagsbuchhandlung, 1929), 202-203. Erich Zenger, "Psalmenexegese," 41-42 expresses doubt about the possibility of the same author being at work, but provides a 
the same motif of speech ("tongues") as swords which is also found in Pss 52 and 55 and which can be traced to the influence of Jer 9:2 and 7 in these two psalms. ${ }^{20}$ It seems that the whole cluster of psalms containing biographical headings linked to David and even those which do not have a specific note about David's persecution are connected. In this cluster the themes of trust ${ }^{21}$ in God's protection and his eventual application of justice ${ }^{22}$ against wicked opponents from within the editors' own people, like David and later Jeremiah also experienced, play an important role.

\section{E ECHOES OF DAVID'S LIFE IN PSALM 56}

It is now time to ask how the biographical title which links the contents of the psalm to an incident in the life of David modifies its hermeneutical horizon. Which cues were used (or perhaps provided) by the editors of the Psalter to connect this psalm to a supposed incident in the life of David when he was "seized" by the Philistines in Gath? As Vivian L. Johnson remarks, there is no account in the HB of David being "seized" in Gath, although one can surmise that he must have been apprehended during his first visit. ${ }^{23} 1$ Samuel 21:11-15 and 1 Sam 27 (cf. also chs. 29-30) do tell that David fled to Gath on two occasions because of the relentless pursuit of Saul - once shortly after he realised that Saul wanted to kill him (1 Sam 21:11-15), and once when he had already been a fugitive for a long time (1 Sam 27). As Johnson remarks, it is the first of these encounters with the Philistines which probably fits the contents of the psalm better. ${ }^{24}$

\section{David's Fears}

It is, however, particularly the aspect of fear which provides a direct link between 1 Sam 21:11-15 and the body of Ps $56 .^{25} 1$ Samuel 21:13 says that

host of reasons why the two psalms were prepared for their adjacent placement by the editors. If there is any value in Pierre Auffret's comparison of the structure of the two psalms, there can be little doubt that they were composed by the same person. Cf. Pierre Auffret, Voyez de vos Yeux: Étude structurelle de vingt Psaumes dont le Psaume 119 (VTSup 48; Leiden: Brill, 1993), 57-59.

20 Cf. also the use of the motif of seeking refuge like a bird in Ps 57:2 (also found in Ps 55:7 and connected to Jer 9:1) and the use of "destruction" (הוה) which is taken over from both Pss 52:4 and 9 and 55:12.

21 Seybold, Psalmen, 225 calls בטח a "Grundwort" of faith and confession in Ps 56.

22 God's righteousness and application of justice is what is at stake in Ps 56:8-9.

23 Vivian L. Johnson, David in Distress: His Portrait through the Historical Psalms (LHBOTS 505; New York: T \& T Clark, 2009), 77. Johnson suggests that the phrase "in their hand" does imply that David was taken into custody and that Achish's reproach of his men for "bringing" David to him does imply that he was seized. See Johnson, David in Distress, 79.

24 Johnson, David in Distress, 78.

25 See also Kleer, "Der liebliche Sänger," 99. 
David took the words of the servants of Achish (who were asking whether this was not "David, the king of the land," who had greater fame than Saul, cf. 1 Sam 21:12) to heart, and that he "was very afraid" (וירא מאד). Psalm 56 can be read as providing an explanation of this one and only instance in the books of Samuel where it is openly stated that David was afraid. Psalm 56:4 then explains that trust in God is the answer to such fear ("The day I am afraid, יום אירא, I will put my trust in you"). In the confession of the psalm, in Ps 56:5 and again in 56:12, the psalmist explains that he will "exult" in the word of God (לא אירא) (לאר) (56:5) and will actually not be afraid what can man do to him? It is thus possible to interpret Ps 56 as an exoneration of King David for the fact that he once "was very afraid." ${ }^{26}$ The psalm would then explain that his fear was only temporary; that he soon got hold of himself and overcame his fear through trust in "the word" of God, remembering that his enemies were mere humans and that he had the power of God on his side. The expression "through God I will praise his word" or "through God I will exult in his word" (באלהים אהלל דברו) thus probably refers to trust in some or other promise of God, ${ }^{27}$ since the parallel phrase in Ps 56:5 says "in God I will trust.",28

\section{David's Tears}

It is important to note, however, that in this scenario the description of "David's" difficult circumstances in Ps 56 cannot be attributed to the Philistines completely. It is Saul who remains the principal instigator. When there is talk in the psalm of enemies "pursuing" the suppliant "all day long,", whose "thoughts" are against him "for evil" (לרע, 56:6) "people who "stir up strife, lurk" (צפ, 56:7), "watch" (שמר, 56:7) his "steps" and "wait" for his "life" (נפש, 56:7), then it must be the pursuit of Saul which comes to mind. It was Saul who sent messengers to David's house to "watch" him all night long (שמר, 1 Sam 19:11) ${ }^{31}$ before he finally fled and it was Saul who "sought" the "life" of David (נפש, 1 Sam 20:1). ${ }^{32}$ Only when Ps 56:8 speaks of God "casting

26 As Johnson, David in Distress, 74, remarks, it was a problem to later interpreters and rabbinic writers that David exhibited fear and pretended to be insane.

27 What the contents of "his word" are supposed to be is not clear. Much later, in 2 Sam 7, Yahweh makes a promise to David to which he refers in 2 Sam 7:21 as "your word" (דברד), but apart from that one could only think of Samuel's anointing of David which had the silent implication that he will be the future king in this regard.

28 The same is true of Ps 56:11, where the parallel is simply external between vv. 11 and 12 .

29 Saul himself once went to kill David after three sets of messengers were deterred by the Spirit of the God, and he himself "lay naked all that day and all that night" (1 Sam 19:24).

30 Cf. the use of רעה, "harm" in 1 Sam 20:7.

31 Cf. the use of שמר in Ps 56:7, "they watch my steps."

32 In Ps 56:7, the enemies "wait" for the "life" (נפשש) of the suppliant. 
down" peoples (עמים) in his wrath, can the reader think of the Philistines. ${ }^{33}$ If Saul and his soldiers are then the enemies referred to in Ps 56, the description in the psalm would require that one think of the long years of persecution which David suffered through the hate of Saul. The second visit of David to Gath, when he was received friendly because it was now known that he was an enemy of Saul, is therefore not excluded from the frame of reference of the psalm. ${ }^{34}$ As Johnson explains, in the case of Ps 34, the heading not only reflects the threat to David's life in Gath, but also that of Abraham and Isaac in Gerar and even Samson in Gaza much earlier. ${ }^{35}$ All of these narratives play a role in the exposition of Ps 34. Although the heading thus focuses on David's first experience among the Philistines, the body of the psalm probably reflects the whole history of his flight from Saul.

What is particularly interesting about David's sojourn in Gath according to 1 Sam 27-30, is that his life was then also threatened, but this time by his own men, while he again experienced great distress. We are told that he and all who were with him wept (ויבכו) until they had no more strength to weep (לבכות). ${ }^{36}$ The reason for this was that the wives and children and the property of the whole band of Israelites were robbed from them. We read that David on this occasion "was greatly distressed," because the people spoke of stoning him. He then, however, "strengthened himself" in Yahweh (1 Sam 30:6) and eventually succeeded in resolving the crisis completely. In view of this experience, one can read Ps 56:9 in a new light, since it is now more clear how God had kept count of his "wanderings" and had put his "tears" in his "bottle.", These instances of suffering during the long years when David was

33 Hossfeld and Zenger, Die Psalmen 51-100, 352, connect the reference to peoples with the same motif which was originally part of Ps 57 and which was inserted (in their view) by the editors in Ps 59, and think that it was inserted in Ps 56 only by the people who created the Davidic Psalter 51-72.

34 Johnson, David in Distress, 80 similarly thinks that Ps 56 would fit either 1 Sam 21:10-22:1 or 1 Sam 27, although the thinks the earlier context provides a better fit. In the case of David's second visit, he, however, thinks of the Philistines as the ones who "watch" David's steps since he would be regarded with suspicion.

35 There are striking similarities between the "fear" experienced by the patriarchs in Gen 20 and 26 in the territory of "Abimelech" and by David, while the "error" in calling the king of Gath "Abimelech" in Ps 34:1 might be an attempt to draw attention to this; Samson's terrible fate at the hands of the Philistines provides an explanation for David's fear. Cf. Johnson, David in Distress, 71-72 and 79-80.

361 Sam 30:4.

37 The proposed reconstruction of Godfrey R. Driver, "Psalm 56:9, 'Thou Tellest My Wanderings," JTS 21 (1970): 402-403, typical of the ingenuity of a past generation of Semitic scholars, lacks any textual evidence and does not need serious consideration. 
on the run before Saul were recorded in God's "book" (Ps 56:9), for example in the books of Samuel. ${ }^{38}$

\section{$3 \quad$ David's Triumph: The Connection with Psalms 18 and 34}

Psalm 34 also has a heading which refers to the David's first visit to Gath, therefore Pss 34 and 56 are connected hermeneutically. The contents of Ps 34 can therefore also help the reader to understand the reasons why Ps 56 was designated as a composition of "David" when he was "seized" by the Philistines. In addition to that, as Beat Weber has pointed out, all the psalms with biographical headings coming after Ps 18 (with its note about David's distress having been resolved decisively), should be read from the perspective of David's obligation to give thanks. ${ }^{39}$ In this regard it is interesting that Ps 56:13-14 have echoes from Ps 18: "On me, O God, rest the vows to you; I shall render thank offerings (תודת) to you. For you have delivered my soul from death, yes my feet (רגלי) from falling, that I may walk before God in the light (אור) of life." This can be compared to Ps 18:29, "For it is you who light my lamp (תאיר נרי); Yahweh my God lightens my darkness" and also with Ps 18:37, "You gave a wide place for my steps (צעדי) under me, and my ankles (קרסלי) did not slip"; and even with Ps 18:49, "For this I will praise you (אודד), Yahweh, among the nations, and sing to your name." In the light of Ps 18, which should be read from the perspective of David's final triumph over all his enemies, it is clear that one of the primary objectives of Ps 56 must have been to focus on praise for God's help in difficult circumstances.

The role of Ps 34 in the Psalter, according to Weber, is that it takes up the elements of praise and teaching found in Ps 18, strengthens the latter element, and works with this and the connection with Saul to prepare the cluster of Pss 52-59/60..$^{40}$ It is therefore important to note the elements of "praise" and "teaching" in Ps 34 and to read Ps 56 in this light.

In the case of Ps 34, the direct link between the contents of the psalm and the description of David's experience is of course the fact that he feigned madness. The expression "to pretend to be mad" or literally "to change one's behaviour (or 'feeling' or 'sense') before someone" (שנה את טעם בעין) establishes a direct link between the title and 1 Sam 21:14. As Johnson notes, the use of טעם in a different sense ("to taste") in Ps 34:9 ("Taste and see that Yahweh is good! Blessed is the man who takes refuge in him") most probably served as the cue for connecting Ps 34 with 1 Sam $21 .^{41}$ But there is also

\footnotetext{
38 See also the discussion of Martin Kleer, "Der liebliche Sänger," 99.

39 Weber, “An dem Tag," 293.

40 Weber, “An dem Tag," 301: "Die vereinzelt platzierte Biographie-Psalm 34 nimmt das lobdankende und belehrende Moment von Ps 18 auf, verstärkt letzteres und arbeitet mit diesem und dem Saul-Bezug dem prägnanten Cluster Ps 52-59/60 vor."

41 Johnson, David in Distress, 75.
} 
another link between the contents of the psalm and the story of David's distress in Gath, and this link establishes a connection with Ps 56 as well. We have already noted the lexical link formed through the stem הלל between 1 Sam 21:14 and Ps 56. This root is also used in Ps 34, and on top of that, in a way which forms a link with Ps 56. It occurs in the hitpa' $e$ l in Ps 34:3: "My soul makes its boast (תתהלל) in Yahweh; let the humble hear and be glad." The form of הלל in Ps 56 is a pi'el, but because of the use of the preposition together with it, it closely resembles the meaning of the hithpael form found in Ps 34:3. There, it is also accompanied by the same preposition before "Yahweh." The two uses of הלל can possibly be brought together under the semantic field of "exultation." In both psalms it thus reflects joyous praise for the salvation provided by God or trust in the salvation promised by him. This would consequently contribute to the aspect of thanksgiving in Ps 56.

David's fear and the resolving of his distress when he was apprehended in Gath establishes another link between Ps 34 and Ps 56. The distress of the psalmist is emphasised through repetition in Ps 34. Psalm 34:5, for instance, speaks about Yahweh's rescuing the suppliant "from all his fears" ( ומכל־מגורותי (הצילני ${ }^{42}$ while Ps 34:7 refers to the suppliant being "saved" out of all his "distresses" or "anxieties" (מכל־צרותיו). As has been pointed out, the verb "to fear" (ירא) is mentioned three times in Ps 56. According to the two psalms with biographical headings, David's "fear" was resolved through his taking "refuge" (34:9 and 23) in Yahweh or, alternatively, through his "trust" $(56: 4,5,12)$ in God. This also forms an important shared motif between the contexts of 1 Sam 21, Ps 34 and Ps 56.

The contents of Ps 34 might provide additional information about the reasons why the two psalms were both connected with this particular incident in the life of David, and the reasons why the editors sought moral support from Ps 56. Psalm 34 functions as a declaration of intent to praise Yahweh. Compare in this regard "I will bless Yahweh," אברכה; "his praise shall be in my mouth," in 34:3; and "Magnify Yahweh with me, let us exalt his name!" גדלו ליהוה אתי ונרוממה שמ in 34:4. The reason for the intended praise of Yahweh is because he, when David "called" (קרא in 34:7) to him, answered him and "saved him from all his fears" (מכל־צרותיו הושיעו in 34:7). Psalm 56 similarly speaks about praise: "In God, whose word I praise, I trust" (באלהימ אהלל דברו באלהים בטחתי in 56:5, cf. 11). The psalmist is also aware of his duty to comply with vows he has made: "I will render thank offerings to you" (אשלם תודת לך, 56:13). The reason for praise are the same in Pss 34 and 56. The author of Ps 56 in v. 14 also confesses that his "soul" was "delivered from death" (נצל hip 'il; cf. the use of

42 The noun מגוiר מגורה . refers, entry 4794, according to HALOT: s.vally to an object of dread or horror, so that one can translate "he rescued him from all the things he feared." 
the same verb in 34:18, Yahweh "delivers" the righteous when they cry for help) and it is clear that this will be the subject for praise. In both psalms, God's intervention comes as a result of the suppliant calling (קרא) to him (Ps $34: 7$; cf. 56:10).

The aspect of teaching is particularly strong in Ps 34. It is an acrostic wisdom psalm, exceptionally suited to this function. The focus on praise in Ps 34 is said to be to the benefit of the "afflicted," since they will hear and be glad (34:3). When they take note of the psalmist's experience, they will be saved from shame (34:6). They are invited to listen to the psalmist, because his intention is to "teach" (למד pi 'el) them the fear of Yahweh (34:12). What they should take from the psalm, is that Yahweh saves the life of his servants (34:23), saves them from all their horrors (צרות, 34:7, 18; רעות, 20), protects them against enemies (34:8) and deprivation of what they might need (34:10-11). All that is necessary is to avoid speaking evil (מרמה) (24:14-15) and to do what is good and seek peace (34:15).

It seems that it is possible that the author of Ps 34 was also influenced by Jer 9 . The motifs which are found in Jer 9 and which seem to be reflected in Ps 34 are perhaps too general to substantiate a claim that the author of Ps 34 was aware of the existence of Jer 9, but it is interesting to compare the use of in the hitpa'el in Ps 34:3 with its exact same function in Jer 9:22 (3x) and in 9:23. The author of Ps 34 is doing what Jer 9:23 advises the people to do, namely to "exult" in Yahweh. Psalm 34 also advises against the things which Jer 9 rebukes, namely pretending to pursue peace (שלום) with fellow Israelites while in actual fact deceiving them, and using the tongue (לשון) (לבר) (מרון) to speak) evil (מרמה) (מרע) (Jer 9:7; cf. Ps 34:14).

\section{F THE MESSAGE OF PSALM 56 AS A WHOLE}

In view of the intertextual connections of Ps 56 with the experiences of David during the whole period of his flight from Saul, and the perspective on this provided by Pss 18 and 34, it is probably fair to say that Ps 56 was intended as a demonstration of how fear and distress caused by enmity and ridicule in the life of a righteous person can be made to go away. ${ }^{43}$ When "David" was in a similar situation and experienced fear, he resorted to trust in God. The trust was

43 Dorothea Erbele-Küster emphasises that the trust in this regard is not only an emotional process, but also involves the cognitive "knowing" where David's help will come from. The "Erhörungsgewissheit" is emphasised through the characteristic that such phrases are usually introduced by a demonstrative pronoun. In Ps 56:10, the demonstrative pronoun זr found through which it is acknowledges that Yahweh is on the side of the suppliant. See Dorothea Erbele-Küster, Lesen als Akt des Betens: Eine Rezeptionsästhetik der Psalmen (WMANT 87; Neukirchen: Neukirchener, 2001), 165-167. 
based in God's word and the knowledge that he was intimately involved in all his trials and tribulations, that he would in the end deal with the enemies, that he was on the side of the suppliant and that human opponents could not measure up to his power to save. Through his grace that saves the righteous from death, a future of thanksgiving and praise and life in the presence of God is opened up.

\section{G CONCLUSION}

It seems that an earlier and pre-existent psalm, which probably was a lament or urgent supplication, was transformed by the editors of the second Davidic Psalter into a confession of trust and a promise of praise. They did this by inserting a double "confession" of trust in God and a biographical note connecting the newly re-created psalm to the time of David's distress among the Philistines. Not only the heading with its reference to David's distress, but also the intertextual allusions to Pss 18 and 34 and to Jer 9 and 17, serve to transform the psalm into a prayer which celebrates David's eventual triumph over his enemies through the help of God.

\section{BIBLIOGRAPHY}

Auffret, Pierre. Voyez de vos Yeux: Étude structurelle de vingt Psaumes dont le Psaume 119. Supplements to Vetus Testamentum 48. Leiden: Brill, 1993.

Begg, Christopher T. “'Dove' and 'God(s)' in Ps 56:1.” Ephemerides Theologicae Lovaniensis 64 (1988): 393-396.

Beyerlin, Walter. Der 52. Psalm, Studien zu seiner Einordnung. Stuttgart: Mainz W. Kohlhammer, 1980.

Driver, Godfrey R. "Psalm 56:9, 'Thou tellest my wanderings.'” Journal for Theological Studies 21 (1970): 402-403.

Erbele-Küster, Dorothea. Lesen als Akt des Betens: Eine Rezeptionsästhetik der Psalmen. Wissenschaftliche Monographien zum Alten und Neuen Testament 87. Neukirchen: Neukirchener, 2001.

Fokkelman, Johannes P. 85 Psalms and Job 4-14. Volume 2 of Major Poems of the Hebrew Bible. Assen: Van Gorcum, 2000.

Hossfeld, Frank-Lothar and Erich Zenger. Psalm 51-100. Volume 2 of Die Psalmen. Kommentar zum Alten Testament. Würzburg: Echter, 2002.

Johnson, Vivian. David in Distress: His Portrait through the Historical Psalms. Library of Hebrew Bible/Old Testament Studies 505. New York: T \& T Clark, 2009.

Kittel, Rudolf. Die Psalmen. Kommentar zum Alten Testament 13. Leipzig: A. Deichertsche Verlagsbuchhandlung, 1929.

Kleer, Martin. "Der liebliche Sänger der Psalmen Israels”: Untersuchungen zu David als Dichter und Beter der Psalmen. Bonner Biblische Beiträge 108. Bodenheim: Philo, 1996.

Köhler, Ludwig and Walter Baumgartner. The Hebrew and Aramaic Lexicon of the Old Testament. Edited by Johann Jakob Stamm. Translated by M. E. J. Richardson. Leiden: Brill, 1994. CD-ROM ed., BibleWorks, v.9. 
Kraus, Hans-Joachim. Psalmen 1-63. Volume 1 of Psalmen. Biblischer Kommentar, Altes Testament 15/1. Neukirchen-Vluyn: Neukirchner Verlag, 1960.

Raabe, Paul R. Psalm Structures: A Study of Psalms with Refrains. Sheffield: JSOT Press, 1990.

Seybold, Klaus. Die Psalmen. Handbuch zum Alten Testament I/15. Tübingen: J. C. B. Mohr [Paul Siebeck], 1996.

Tate, Marvin E. Psalms 51-100. Word Biblical Commentary 20. Dallas: Word Books, 1990.

Terrien, Samuel. The Psalms: Strophic Structure and Theological Commentary. The Eerdmans Critical Commentary. Grand Rapids, Mich.: Eerdmans, 2003.

Van der Lugt, Pieter. Psalms 42-89. Volume 2 of Cantos and Strophes in Biblical Hebrew Poetry. Leiden: Brill, 2010.

Weber, Beat. "Zum sogenannten 'Stimmungsumschwung' in Psalm 13." Pages 116138 in The Book of Psalms: Composition and Reception. Edited by Peter W. Flint and Patrick D. Miller. Supplements to Vetus Testamentum. Leiden: Brill, 2005.

. “An dem Tag, als JHWH ihn rettete aus der Hand aller seiener Feinde und aus der Hand Sauls' (Ps 18:1): Erwägungen zur Anordnung der biographischen Angaben zu David im Psalter." Vetus Testamentum 64 (2014): 284-304.

Weber, Beat. Die Psalmen 1 bis 72. Volume 1 of Werkbuch Psalmen. Stuttgart: Kohlhammer, 2001.

Zenger, Erich. "Psalmenexegese und Psalterexegese: Eine Forschungsskizze." Pages 17-65 in The Composition of the Book of Psalms. Edited by Erich Zenger. Bibliotheca Ephemeridum Theologicarum Lovaniensium 238. Leuven: Peeters, 2010.

J. Henk Potgieter, Department of Ancient Languages and Cultures, University of Pretoria, 0002, Pretoria, South Africa. Email: henk.potgieter@up.ac.za 